Barriers to Investment by Russian Firms:

Property Protection or Credit Constraints?

\author{
By: Susan J. Linz
}

William Davidson Working Paper Number 469

May 2002 
Barriers to Investment by Russian Firms: Property Protection or Credit Constraints?

\author{
Susan J. Linz \\ Department of Economics \\ Michigan State University \\ East Lansing, Michigan 48824-1038 USA \\ (517) 353-7280 \\ linz@msu.edu \\ Research Fellow \\ William Davidson Institute \\ University of Michigan
}

May 2002

Funding for data collection provided by Michigan State University and by a grant from the International Research and Exchanges Board (IREX), with funds provided by the U.S. Department of State (Title VIII Program) and the National Endowment for the Humanities. None of these organizations is responsible for the views expressed. 
William Davidson Institute Working Paper 469

\title{
Barriers to Investment by Russian Firms: Property Protection or Credit Constraints?
}

\begin{abstract}
A multitude of explanations for low investment by Russian firms have been offered: high inflation, high interest rates, falling production, falling GDP, an underdeveloped banking system, a confiscatory tax regime, calls for the re-nationalization of industry, excessive regulations, and an underdeveloped legal system, among others. This paper's basic premise is that investment in Russia will not occur if firms are unable to ensure the security of their property and property rights; that is, if the risk of destruction or expropriation is high. Nor will investment occur if access to investment funds is limited. Data collected from 264 Russian firms in the spring and fall 2001 are used to construct a security index and credit index in order to evaluate the relative importance of property protection and access to financing on the investment activities of manufacturing, retail, and other service sector firms in Moscow, Rostov, Taganrog, and Vladivostok. For the firms participating in this survey, the reported percentage of profit reinvested is significantly higher among firms which responded positively to questions about the effectiveness of police and courts in protecting their property and property rights, and significantly lower among firms which made above-average payments (official and unofficial) for property protection. Unofficial payments alone lower investment by $20 \%$. Firms with access to credit reported reinvesting a significantly greater share of their profits. All other things equal, firms in Moscow, and firms in food processing and food distribution reinvested a significantly greater share of their profits. Manufacturing firms reported reinvesting a significantly smaller share of their profits in comparison to retail shops or other service sector companies. These results do not vary with the amount of collateral a firm has; that is, whether the firm owns or leases its premises.
\end{abstract}

Key words: Russia, investment, property protection, credit, transition cost JEL Classification: P26, P31, L21 
Barriers to Investment by Russian Firms: Property Protection or Credit Constraints?

\section{Introduction}

Russia began its transition from a centrally planned economy to a market economy in January 1992 with an outdated, if not obsolete capital stock, as well as an underdeveloped infrastructure. It was generally accepted that for Russia to successfully compete in domestic or global markets: (1) existing enterprises would have to restructure their operations and renovate their production facilities; (2) new firms would have to be established to provide distribution/information/financial and other services which were not available in the former socialist economy; and (3) both activities would require substantial investment. Nearly a decade has passed. Russia remains one of the wealthiest countries in the world in terms of natural resources and the percentage of population with advanced education. Moreover, there appears to be no shortage of financial capital - capital flight from Russia each year has been estimated by the billions of dollars. ${ }^{1}$ Yet, we observe low investment in Russia. ${ }^{2}$ Why?

A multitude of explanations for low investment in Russia have been offered: high inflation, high interest rates, falling production, falling GDP, an underdeveloped banking system, a confiscatory tax regime, calls for the re-nationalization of industry, excessive regulations, and an underdeveloped legal

\footnotetext{
${ }^{1}$ Estimates by Russia's national police agency, the MVD, put the amount of money illegally leaving Russia each year at $\$ 9$ billion, with total capital flight running more than $\$ 15$ billion per year during the 1990s (See report in Transition, August 1999 p. 11). Between December 1991 and December 1998, Hedlund (1999) estimates that capital flight from Russia totaled $\$ 350$ billion. See Stefan Hedlund, "Russia’s Oligarchs Stole the State Machinery," Transition vol 10, no 4 (Washington DC: World Bank and William Davidson Institute), August, pp. 17-19. More recently, analysts at Moscow's Alfa Bank estimate that capital flight in 2001at will reach \$28 billion, stating that "capital flight is unlikely to decline over the next few years" (p. 18). See Natalia Orlova and Andrei Roudenko, "Cross-Subsidization: Roadblock to Reform,” (Moscow: Alfa Bank, 29 June 2001), pp. 1-19.

${ }^{2}$ Goskomstat (2000) reports that investment fell steadily throughout most of the 1990s: from $46 \%$ of the 1990 level in 1992 to $18 \%$ of the 1990 level in 1997, before exhibiting a slight increase (1\%) in 1999.
} 


\section{William Davidson Institute Working Paper 469}

system, among others (EBRD 1995 1999). Using the foundation established by Grossman and Helpman (1994), Frye and Shleifer (1997), Johnson et al (1999a), Johnson et al (1999b), Gaviria (2000), Hellman and Schankerman (2000), and Pissarides et al (2000), this paper investigates two barriers to investment by Russian firms: property protection and credit constraints. The paper's basic premise is that investment by Russian firms will not occur if firms are unable to ensure the security of their property and property rights; that is, if the risk of destruction or expropriation is high. Nor will investment occur if access to investment funds is limited (no profits for reinvestment, or prohibitively high interest rates on bank loans, for example) or if the return associated with reinvesting is lower than the firm would receive by investing elsewhere. ${ }^{3}$

Why is it important to investigate factors contributing to low investment among Russian firms? Without investment to renovate and expand the existing capital stock, manufacturing firms will remain uncompetitive in domestic and global markets, and service sector firms, including retail shops, will be limited in their ability to meet domestic demand. If investment is positively correlated to the pace of transforming an economy from plan to market, as conventional wisdom suggests, then low investment will delay the successful completion of Russia's transition to a full-fledged market economy. Low investment will impede improvements in Russia's overall standard of living.

Analyzing the investment activities of manufacturing firms, retail shops and other service sector companies permits comparison of strategic firm behavior across sectors of the Russian economy. While the majority of studies of Russia's transition focus on the performance and restructuring efforts of

\footnotetext{
${ }^{3}$ In the mid- to late 1990s, investing in short term government bonds, GKOs, was the most lucrative opportunity for Russian firms: rates of return on GKOs exceeded every alternative investment option in Russia (Gregory and Stuart 2000, Millar 2000). During formal and informal discussions conducted in early summer 1998 and in the fall of 1999 , Russian managers and banking officials alike describe ways they channeled funds into GKOs rather than use the cash to cover ongoing operational expenses.
} 


\section{William Davidson Institute Working Paper 469}

privatized manufacturing firms, the inclusion of retail shops and newly-created (de novo) firms provides an opportunity to investigate sectors of the economy that are more or less thriving, and thus financially able to undertake investment options. Moreover, among retail shops and de novo firms, the magnitude of required investment is likely much less than for manufacturing firms, and, thus, more likely to occur. It may be, for example, that among manufacturing firms investment is "lumpy;" that is, the minimal investment is larger than retained earnings can accommodate (Rajan and Zingales 1998). Furthermore, in Russia's transition economy, actual investment requirements among retail shops and de novo firms may be more similar than investment requirements among manufacturing firms, possibly even among manufacturing firms in the same industry. When actual investment requirements are approximately the same across firms, patterns in investment strategies and financing are easier to discern. Finally, retail shops and de novo firms, because most were established during the transition period, have been less likely to exhibit the Soviet legacy of secrecy, ${ }^{4}$ where even the most mundane operating information is considered to be a "state secret." Consequently, the possibilities for getting appropriate information for this analysis are much greater than if the research project focused exclusively on former state-owned manufacturing firms.

Does it matter whether the lack of protection is relatively more important than the lack of financing in contributing to the low investment level in Russia? If the lack of property protection is a deciding factor in the investment decision, policies which simply inject money into the economy to loosen liquidity constraints will have little real consequence for production or employment. The data collected for this paper, as well as from ongoing projects on similar topics (see, for example, Frye and

\footnotetext{
${ }^{4}$ For detailed discussion, see Maksim Boycko, Andrei Shleifer and Robert Vishny, Privatizing Russia (Cambridge: MIT Press, 1995), and Joseph Blasi, Maya Kroumova and Douglas Kruse, Kremlin Kapitalism: Privatizing the
} 
Shleifer 1997, Johnson et al 2000), will be useful in guiding policymakers regarding ways to improve the environment for both domestic and foreign investors. With nearly $50 \%$ of the Russian population currently living in poverty conditions (Goskomstat 2000), in a country that produces and exports more oil than the rest of the world, it is hard to imagine that this is a cost which policymakers can continue to ignore. Moreover, despite the relatively small number of participating firms, these data add to our understanding of the ways in which the investment environment has changed since the financial crisis of August 1998 and the tax legislation adopted in 2000. ${ }^{5}$ As such, it furthers our knowledge of how shocks and policy choices affect the investment strategies adopted by Russian firms.

The paper, utilizing firm-level data collected from a survey conducted in April 2001 in Moscow, Rostov and Taganrog, and in September 2001 in Vladivostok, is divided into four parts. Part I describes the project design and research methodology. To examine the determinants of the firm's decision to reinvest its profits, the project design involved a sample selection strategy to include firms engaged in investment activities. Consequently, both privatized and newly-created private (de novo) firms in both manufacturing and non-manufacturing sectors were contacted for participation. Part II summarizes characteristics of the 264 participating firms. Part III presents the empirical results. These data indicate that the reported percentage of profit reinvested is significantly higher among firms which respond positively to questions about the effectiveness of police and courts in protecting property and property rights, and significantly lower among firms which make above-average payments (official and unofficial) for property protection. Unofficial payments alone account for a $20 \%$ reduction in

\section{Russian Economy (Ithaca: Cornell University Press, 1997).}

${ }^{5}$ Legislation simplifying the tax codes is in its final stages of adoption. Informal discussions with numerous businessmen suggest that, even now, the tax system has improved significantly, increasing their willingness to pay their tax obligations. 
investment. Firms with access to credit report reinvesting a significantly greater share of their profits. All other things equal, firms in Moscow, and firms in food processing and food distribution reinvest a significantly greater share of their profits. Manufacturing firms report reinvesting a significantly smaller share of their profits in comparison to retail shops or other service sector companies. Part IV offers concluding remarks.

\section{Project Design and Research Methodology}

The research project's primary objective is to determine the relative importance of property protection and access to credit in the investment decisions of Russian firms, using owners/managers as the primary source of information. Six hypotheses governed the project design, which in turn influenced the development of the survey instrument:

- The magnitude of re-investment by the firm is inversely related to manager's perception of the risk associated with protecting the investment.

The manager's perception of the need to offset risk is directly related to the magnitude of payments made for the protection of the firm's property, as well as to the magnitude of the bribes/extortion payments made by the firm to protect its property rights (the right to realize a financial gain from the operation of the business).

- Re-investment by the firm is directly related to manager's perception of the effectiveness of the court in upholding contracts and resolving business disputes.

- Re-investment by the firm is directly related to the profitability of the firm and/or the firm's access to bank credit (or loans from other firms).

- Profitability of the firm, and thus re-investment, is inversely related to the magnitude of official and unofficial payments that the firm is required to make (taxes and protection payments/bribes as a percent of sales). ${ }^{6}$

\footnotetext{
${ }^{6}$ In a catch-22 situation, protection payments enhance the security of the firm's property and property rights, yet at the same time reduce the ability of the firm to finance investment expenditures using internal sources. Without protection payments, investment is unlikely; with protection payments, internal financing options are reduced, making investment unlikely. Moreover, as the banking system develops, expanding the firm's external options for investment financing, it may likely happen that the magnitude of the firms' protection payments simply increases. What is to stop this outcome?
} 


\section{William Davidson Institute Working Paper 469}

Access to bank credit for investment purposes is directly related to the profitability and previous loan experience of the firm.

To obtain the requisite data to test these hypotheses, owners or top-level managers were asked to complete a questionnaire which addressed numerous aspects of their firm's current conditions. ${ }^{7}$ In addition, in-depth interviews were conducted with owners or top-level managers in a variety of firms to follow up on select topics in greater detail.

Funding constraints limited the scope of the project in two ways: first, by restricting the number of locations which could be included in the survey; and second, by precluding the selection of a representative sample of firms. ${ }^{8}$ Firms in Moscow, Rostov, Taganrog, and Vladivostok, locations selected in part to capture regional differences and in part to maintain ongoing research collaboration, ${ }^{9}$ were asked to participate in the project. The objective in contacting firms to participate was to include as wide a variety as possible within the three main categories: retail shops, manufacturing, other (nonretail) service sector firms, as well as to target firms which had been in operation prior to 1998 . Project questionnaires were designed to elicit information which could be used to construct a

\footnotetext{
${ }^{7}$ To capture differences in the firms' initial conditions, as well as differences in the relative impact of the transition process on the firm's current situation, three questionnaires were developed for the project: one to be administered to retail shops, one for manufacturing firms (former state-owned enterprises), and one for newly-created private businesses outside of the retail sector. I thank Maria Petrenko and Irina Tsaturova for assistance with the translation and back-translation of the questionnaires, and Inna Petrova, Mikhail Morozov, and Larissa Chouripa for assistance with the data collection. Anatoly Nepomnyashchy was instrumental in organizing the data collection for a pilot study for this project in October 1999.

${ }^{8}$ Funds were not available to gather information about the population of firms in each location; consequently, selecting a representative sample of firms for each location was not an option.

9 Moscow's position as Russia's financial hub makes it worthy of study, especially in light of a "capital city effect" found in numerous studies that focus on the overall performance of Russian firms. See, for example, Frye and Zhuravskaya (1999), Linz and Krueger (1998), and Linz (2000). Taganrog, located approximately 100 kilometers from Rostov, has been identified by Soviet and Russian scholars alike as the average Russian city (Grushin 1980, Rimashevskaya 1993, Chichilymov 1999); the "Peoria" of Russia. Including Vladivostok, one the top five locations in Russia receiving foreign direct investment, offers a perspective on the progress of the transition from the Far East.
} 


\section{William Davidson Institute Working Paper 469}

security index to measure the extent to which firms perceive their property and property rights are protected, and a credit index to measure a firm's access to external financing. Regression analysis is used to evaluate the relative significance of property protection and access to credit on a firm's investment activities. In particular, the dependent variable is the percentage of profits that the firm reports reinvesting. ${ }^{10}$

Investment and the Security of Property and Property Rights

The project starts from the premise that the security of property and property rights involves two distinct components: protecting property from vandalism or destruction, and protecting property rights, that is, the right to realize financial gain from property. Numerous studies link evaluations of property and property rights security to investment (Johnson et al 1999 2000, Knack and Keefer 1995, Mauro 1995, Svensson 1998, Demirguc-Kunt and Maksimovic 1998), demonstrating that investment is lower when property protection is not assured.

The desire for property protection among Russian businessmen is highlighted in response patterns to questions in this survey which asked participants about the usefulness of establishing a Federal Property Protection Agency (Braguinsky and Yavlinsky 2000) and their willingness to pay for such an organization. Of the 259 participants responding in the spring and fall of $2001,91 \%$ said that a

\footnotetext{
${ }^{10}$ Experience indicates that Russian firms are reluctant to discuss current financial conditions in any detail. Moreover, if this information is the focus of a survey question or informal conversation, owner/managers tend to misrepresent actual conditions and describe their firm as having a worse financial situation than all other indicators suggest. Consequently, the question used in this analysis, for manufacturing firms, reads:

Did your firm earn a profit last year? Yes No. If yes, what percent of profits were re-invested into the future development of the firm? For retail shops and de novo firms, the question reads: Did your firm earn a profit in its first year of operations? ___ Yes ___ No. If yes, what percent of profits were re-invested into the future development of the firm? Implicit in this analysis is the assumption that the firm's investment strategy in the previous year, or in the first year of operations, signals the firm's ongoing commitment to the development of the company.
} 


\section{William Davidson Institute Working Paper 469}

specially formed federal organization to protect property would be desirable to the current situation of relying on the local police force; $92 \%$ said they would agree to pay for such an organization. ${ }^{11}$ Nearly three-quarters of these firms responded affirmatively to a question which asked if their company made bribe payments (vzyatki) in the past year. At the same time, however, only $20 \%$ of those responding selected "crime or criminal situation" as a major obstacle to the prosperity of their firm.

How will the security of property and property rights be measured? A security index is developed which involves both a positive and negative component. The positive component incorporates the manager/owner's perspective of the effectiveness of the police and courts in protecting the firm's property and property rights. I hypothesize that owners/managers' perception of the security of their firm's property and property rights is likely to be higher if they believe the police and courts are effective. Three questions in the survey instrument addressed the effectiveness of the police and courts:

- Do the police work effectively and conscientiously to protect the property and rights of businessmen? Yes $=1$.

MILITSIA

- When you asked the police for assistance, were your requests, claims, problems solved with the help of the police? That is, were you satisfied with the results of police assistance? Firms were given the choice of: (1) always satisfied; (2) mostly satisfied; (3) neutral; (4) mostly not satisfied; (5) never satisfied. The first three response options were coded as $=1$; options 4-5 were coded as $=0$.

SATISFY

- In your view, does the court work effectively to protect the rights and property of business? Yes $=1$.

COURTWEL

An additive index, PROTECT1, is constructed which has a maximum value of three; the higher the

\footnotetext{
11 Those who opposed the idea explained that it would simply create "another mouth to feed."
} 
index value, the more secure/protected the company feels. ${ }^{12}$ I posit a direct relationship between the index value and the percentage of profits which a firm reinvests.

The negative component of the security index incorporates the managers' perceptions of the need for protection, as well as the official and unofficial payments a firm makes for protection.

Managers' perception of a lack of security will likely coincide with expenditures on protection, which in Russia involves both official and unofficial payments. The correlation between perception of security and payments for security is somewhat obscured, however. The existence of protection payments indicates that the firm finds such payments necessary; local authorities are not sufficient to provide the requisite protection. Yet, the existence of official or unofficial payments reflects the fact that the firm has undertaken the payment required for protection, and thus is likely to feel more secure. Discussions with Russian businessmen, both formally and informally during numerous visits in previous years, plus the results provided by Johnson et al (1999 2000), Frye and Khuravskaya (1999), and Friedman et al (2000), for example, suggest that the existence of protection payments signals a lack of property and property rights security. Consequently, the interpretation that protection payments signal lack of security is given more weight in this analysis. That is, if firms are obliged to contact the police for protection, or if firms make official or unofficial protection payments, their perceived level of security is low, and thus I expect to find a lower percentage of profits reinvested.

Five questions in the survey instrument address the negative component of the security index:

\footnotetext{
12 Johnson et al (1999) discuss the relative merits of an additive index over an either/or index. Their data show that the security effects are additive. For the either/or index to dominate the explanation of firm behavior, multiple bribetakers would have to coordinate their actions (Shleifer and Vishny 1993, 1998). Given the Johnson et al results and results from in-depth interviews with dozens of Russian managers which I conducted, I elected to utilize the additive formulation.
} 
During the last two years, did you ask the police for assistance $?^{13}$ Yes $=1$. ASKPOLC

Does your company employ personnel to guard the shop (business premises) or merchandise? Yes $=1$.

SECURITY

Does your company hire another organization or person for security / protection purposes ${ }^{14}$ Yes $=1$.

BUYSEC

During the last year, did your company make bribe payments (vzyatki) $?^{15}$ Yes $=1$

BRIBE

When you were called to the court as a defendant by local or other authorities, do you think it would have been possible to avoid the charge or avoid the court by making a bribe payment? Yes $=1$.

BRIBECRT

The maximum value for this index, PROTECT2, is five. The higher the index value, the smaller the percentage of profits a firm is likely to reinvest: (1) firms making payments for protection, and thus scoring high on this index, only do so because without payment their firm is at risk; (2) firms scoring high on this index undertake a greater the expense to protect property and this expense is typically paid out of profits.

To capture the relative significance on investment of unofficial security payments, the two bribe questions are used to construct an extortion index, EXTORT. It is likely that while the scope of this index is less, covering only bribe payments rather than the sum of all types of security payments, the

\footnotetext{
${ }^{13}$ The question, as asked, does not distinguish between asking the police to investigate a theft or act of vandalism (ex poste) and asking the police for assistance in protecting against theft or vandalism (ex ante). While respondents described both types of requests, one could argue that both would be associated with a perception of a lack of security.

${ }^{14}$ The two questions about the employment of security personnel were designed to capture whether the firm's security was provided in-house or by an outside contractor, but they need not be mutually exclusive. It is not clear from the response patterns, however, whether participants noticed the intended distinction: insider versus outsider in the provision of security. Of the firms responding to the two questions, 134 (>70\%) replied "yes" to both.

${ }^{15}$ This question assumes that bribe payments are made only when necessary; that is, to protect the property or property rights of the firm. Follow up questions asked the firm to indicate how often bribe payments were made in the past year, and to how many different organizations.
} 
influence of EXTORT on the firm's investment activities will be greater than PROTECT2. In my view, the cost to the Russian economy of the unofficial payments upon which most activity is based will be documented by the coefficient which emerges on this variable in the regression analysis. That is, the coefficient on EXTORT will signal the foregone investment by Russian firms each year. It is this figure for which policymakers should be held accountable in calculations of the excess cost of the transition on the Russian people.

Since the security index incorporates both positive and negative components, it makes no sense to combine them into a single measure. In the regression analysis, PROTECT1 and PROTECT2 are both included. I hypothesize that the percentage of profits that a firm reinvests will vary directly with PROTECT1 and inversely with PROTECT2. Similarly, when EXTORT is included in the regression in place of PROTECT2, I expect a negative coefficient.

\section{Investment and Access to Financing}

Investment is required to start up a new business as well as to renovate or expand an existing business. I assume that firms will not finance investment projects which cannot be protected.

Both internal and external sources of financing are potentially available to Russian firms. To control for differences in current financial conditions, firms were asked a number of questions about their general financial well-being. Several questions were designed to address the availability of internal financing:

\footnotetext{
- Does your firm plan to do major repairs (kapital'nyi remont) this year? ${ }^{16}$ _ yes _ no If yes, how will it be financed? ___ from profits; ___ loan from bank; borrow from friends, acquaintances, other businessmen; other (please specify).

${ }^{16}$ Firms also were asked about the percentage of their capital stock which needed replacing. Managers reported that, on average, $34 \%$ of their capital needed replacing.
} 
Compared to last year, what will be the sales volume, or volume of operations of the company this year? higher the same lower.

VOLUME

Compared to last year, what do you expect the financial situation of your firm to be this year? better the same worse.

POSITION

What do you think is the main obstacle to the prosperity of your firm? the firm lacks money; criminal situation; customers lack money; o tax system;

These questions make it possible to categorize firms as "likely to invest" and "unlikely to invest." That is, if a firm responds affirmatively to undertake major capital repair, increased sales volume, or improved financial situation, and negatively to the firm lacks of money, and criminal situation then it is categorized as "likely to invest." Only one firm in this survey emerged as "likely to invest" when using the five-part criteria. ${ }^{17}$ Internal financial conditions are only one component of the investment decision, however. The availability of external financing also is likely to influence the firm's investment activities.

To construct a credit index, a series of questions were included to identify access to external financing. Two questions in the survey instrument addressed the general activity of borrowing:

Did the company borrow to buy products or merchandise during the last two years? Yes $=1$.

BORROW

In the last two years, did the company borrow to pay wages? Yes $=1$.

BOROWW

Two questions were more specific about the source of external financing:

In the last two years, did your company take out a loan from the bank in order to support or develop the business? Yes $=1$.

BANKLOAN

\footnotetext{
${ }^{17}$ Not surprisingly, when the criteria are relaxed, more firms emerge as "likely to invest." For example, when using only the first three conditions (plans for renovation, improved sales, better financial position), twenty-three firms are categorized as "likely to invest;" when using the last three conditions, thirty-eight firms emerged as "likely to invest."
} 
In the last two years, did your company borrow from private individuals or other companies in order to support or develop the business? Yes $=1$.

The credit index has a maximum value of four; the higher the index value, the greater the access to external financing. ${ }^{18}$ Firms that score above the mean $(=2)$ are viewed as more likely to undertake investment projects. ${ }^{19}$

Regression analysis will be used to evaluate the relative importance of property protection and access to financing on the investment activities of the participating Russian firms. In this study, the dependent variable is the percentage of profits which the firm reports re-investing. The independent variables include both components of the security index (PROTECT1, PROTECT2) and the credit index, with controls added to capture variation in investment explained by location (Moscow), ${ }^{20}$ industry $^{21}$, ownership (lease or own buildings), ${ }^{22}$ average wage, ${ }^{23}$ and size of firm (as measured by

18 Among the firms participating in this study, the response patterns generate a relatively low correlation between bank loan and loan from another business (.2331); eighteen firms report borrowing from both sources in the past two years.

${ }^{19}$ Twenty-three of the 108 firms which responded positively to external financing scored higher than two on the credit index.

${ }^{20}$ Firms in Moscow have greater access to external financing, given the fact that Moscow is the financial hub of the Russian Federation; thus the ability to invest may be higher in Moscow than in the provinces. Competition is higher in Moscow, given the relative availability of imported goods; thus the incentive to invest may be higher in Moscow than in the provinces.

${ }^{21}$ Firms in expanding industries like food processing are likely faced with more investment opportunities than firms in declining industries (machine building, for example). Firms in capital-intensive industries (machine building) are likely to confront greater inves tment expenditures / a higher magnitude of required investment / than firms in less capitalintensive industries (clothing, food processing).

${ }^{22}$ The decision to own or lease the facilities may depend upon the financial condition of the firm, as well as on the perception of property and property rights security.

${ }^{23}$ Several questions addressed the financial condition of the firm, with conflicting results. Average wage represents the best proxy for the firm's financial condition. Controlling for industry and regional differences in wage rates, firms reporting profits tend to be firms which pay above-average wages; the correlation coefficients range from .3568 to .4518 , depending on the industry and region. 
number of employees). ${ }^{24}$ In a second specification, change in financial position and change volume of operations (sales), both variables referring to changes over the previous year, also are included as controls to capture the extent to which re-investment may be driven by changes the firm's financial conditions. In a third specification, the credit index is redefined from the additive index used initially, to an either/or $(0,1)$ access to external financing index (LOAN). That is, if the firm reports any external financing, the value is one; otherwise the value is zero. If the LOAN coefficient is significant and the explanatory power of the specification is higher, this implies that the existence of external financing rather than the multiple sources of external financing influences the firm's investment activities.

The variable list, variable means, and variable definitions are provided in Appendix A. The following section provides a description of the Russian firms participating in the survey.

\section{Characteristics of the Participating Firms}

In April and September, 2001, two hundred sixty-four firms participated in a survey that focused on barriers to investment among Russian firms. ${ }^{25}$ As seen in Table 1, of the participating firms, 40 were located in Moscow, 35 in Rostov, 139 in Taganrog, ${ }^{26}$ and 50 in Vladivostok. Nearly half of the participating firms engaged in retail trade (46\%); approximately one-quarter (24\%) offered other services to businesses and consumers. Among these, the majority (64\%) of non-manufacturing firms were established after $1995 .^{27}$ Just under one-third (30\%) of the participating firms were involved in

\footnotetext{
${ }^{24}$ Larger firms are expected to have higher investment requirements than smaller firms.

${ }^{25}$ Altogether, some 307 firms were contacted. Thus, the response rate was $86 \%$.

${ }^{26}$ Includes 3 firms located in Azov.
} 


\section{William Davidson Institute Working Paper 469}

manufacturing.

The distribution of firms by main product type is given in Table 1. Over one-third of the participating firms were involved in the production or distribution of food products. The production or distribution of consumer goods and other durables (including office equipment) accounted for $28 \%$ of the participating firms. Manufacturers of machinery and equipment and other producer goods comprised 5\%, with firms producing or distributing construction materials accounting for $9 \%$ of the participating firms. Less than half $(46 \%)$ of the participating firms owned the building(s) in which their company operates; in Taganrog, the smallest of the four locations, the ownership rate is significantly higher $(70 \%)$.

Given the composition of the sample, it is not surprising that nearly half of the firms participating in the survey project employ 25 or fewer workers. Among the retail shops, however, the average number of employees totals 43 , due to the number of companies which operate shops in several locations and employ, in total, over 150 workers. The manufacturing firms participating in this survey report employing, on average, 373 workers.

At least three-quarters of the participating firms report profits; in Moscow, the reported percentage is much higher (92.5\%). Firms in Moscow and Vladivostok report reinvesting a greater share of their profits than firms in Rostov and Taganrog (see Table 1). This result holds when type of firm is held constant; that is, among retail shops, reinvested profits average $62 \%$ in Moscow, $86 \%$ in Vladivostok, $19 \%$ in Taganrog, and 14\% in Rostov. At the same time, the percentage of retail shops that report borrowing to cover working capital expenses accounts for nearly $78 \%$ of the Moscow firms,

${ }^{27}$ Only these two groups of firms, retail shops and de novo firms, were asked about the year in which the company was established. 


\section{William Davidson Institute Working Paper 469}

$30 \%$ of the participating shops in Vladivostok, and $11 \%$ of the shops in Taganrog.

Firms participating in this survey were more likely to borrow from other companies than from banks: $8 \%$ of the firms in Moscow borrowed from the bank, while $80 \%$ reported borrowing from other firms. Outside of Moscow, borrowing from other firms was significantly less prevalent, in general, and among the retail shops, in particular, borrowing from other firms was much less than their counterparts in Moscow.

Wages varied dramatically by geographical location. Among the retail shops participating in this project, wages were significantly higher in Moscow (5214 rubles) than in Rostov (2010 rubles), Taganrog (1440 rubles), or Vladivostok (4007 rubles). Outside of Moscow, retail employees were paid, on average, about the same as manufacturing employees (2014 rubles compared to 2010 rubles), and somewhat less than other service sector workers (2271 rubles). Excluding Rostov, only $10 \%$ of the firms report borrowing money in the last two years to cover their wage bill.

The figures reported in Table 1 refer to the entire set of participating firms. In Moscow, all of the participating firms were retail shops. Consequently, a more useful comparison focuses on similarities and differences among retail shops in the four regions. For example, among Moscow shops, nearly all report paying bribes (97.5\%); compared to $75 \%$ of the participating firms in Taganrog, $69 \%$ of the firms in Rostov, and $48 \%$ of the firms in Vladivostok. When the comparison is limited to retail shops, the regional differences become somewhat smaller, but the difference between the provinces and Moscow remains significant. That is, $70 \%$ of the retail shops in Taganrog and Rostov, and $65 \%$ of the retail shops in Vladivostok report making bribe payments; compared to about $98 \%$ of the retail shops in Moscow. A similar pattern is found in responses to the questions about the volume of sales and 


\section{William Davidson Institute Working Paper 469}

financial position, as well as the percentage of capital and labor that needs replacement: regional variation diminishes when only retail shops are included in the analysis, but there remains a significant difference between response patterns of Moscow shops and shops in the provinces. ${ }^{28}$ Moscow is not a leader in terms of changes associated with the transition process when considering the number of shops engaged in barter transactions (in all four regions the percentage of shops reporting barter transactions is about 20-25\%); nor is Moscow a leader with regard to membership in professional associations or trade groups: in this case, a greater proportion of firms in Vladivostok respond affirmatively (see Table 1).

\section{Investment Strategies: A descriptive analysis}

The survey instrument included a number of questions related to the firm's actual and planned investment activities. For example, survey participants were asked about plans to renovate and how the renovation was to be financed. Participants also were asked what percentage of the firm's capital stock needs replacing. Finally, participants were asked about the percentage of profit which the firm reinvests.

As seen in Table 1, firms report that an average of $25 \%$ to $35 \%$ of their capital stock needs replacing; among manufacturing firms, the average exceeds $40 \% .^{29}$ Firms in heavy industry report that between $25 \%$ and $90 \%$ of their capital stock needs replacing.

While the potential demand for investment is high among Russian firms, plans for renovation are limited. Of the 261 firms responding to the question, just over $20 \%$ report current plans to renovate

\footnotetext{
${ }^{28}$ In two instances, financial position and volume of sales, Vladivostok response patterns are closer to Moscow than to Rostov and Taganrog.

${ }^{29}$ By contrast, firms report the need to replace only $5-15 \%$ of their current workforce, depending upon the region and sector in which the firm is located.
} 


\section{William Davidson Institute Working Paper 469}

their capital stock. Of these, the majority (nearly two-thirds) intended to finance the renovations from profits; less than one-quarter indicated that their plans for renovation would be financed by personal funds; $15 \%$ indicated they would borrow, either from the bank or from other businesses, to finance the renovations.

All firms were asked about the percentage of profits which they reinvest. A total of 210 firms reported reinvesting a portion of their profits. In comparison to the manufacturing firms participating in the survey, retail and other service sector firms report reinvesting a significantly greater percentage of their profits: that is, among retail shops, reinvestment averaged $43 \%$, compared to $19 \%$ among manufacturing firms. Among the participating retail shops, reported reinvestment averaged over $86 \%$ in Vladivostok, $62 \%$ in Moscow, $14 \%$ in Rostov, and $19 \%$ in Taganrog. ${ }^{30}$

In comparison to heavy industry firms (producers and distributors), firms involved in the processing or distribution of food products and firms involved in services report reinvesting a significantly greater percentage of profits.

The percentage of profits reinvested does not vary by firm's reported change in financial position. That is, the reported percentage of profits reinvested does not depend upon whether the firm says its financial position is better, the same, or worse than last year. However, the percentage of profits reinvested does vary in accordance with whether or not the firm reports itself as having no money (lack of money is the most important obstacle to its current operations).

Data collected from these firms are used to examine the relative importance of property protection and access to credit in explaining the variation in investment.

\footnotetext{
${ }^{30}$ In comparison to participating firms in Taganrog, firms in Moscow (all retail) and firms in Vladivostok (retail, manufacturing and services) reinvest significantly more profits.
} 


\section{William Davidson Institute Working Paper 469}

\section{Empirical Results}

To what extent are investment expenditures influenced by the perceived level of security and/or access to external financing? Table 2 summarizes the response patterns for both the security index (PROTECT1 and PROTECT2) and the credit index. As seen in column 1, the 264 firms participating in this survey displayed a low regard for the effectiveness of the police and courts. A score of 1.5 on PROTECT1 signals a neutral perception of the effectiveness of the official providers of security in the Russian economy. The mean score for PROTECT1 for the firms participating in this survey is 0.40 , significantly lower than the neutral score. While there is variation in the mean score by region: firms in Vladivostok have a significantly higher regard for the police and courts than firms in Moscow, Rostov or Taganrog; as well as variation by type of firm: owners of retail shops have a significantly higher regard for the police and courts than owners of other service sector companies or managers of manufacturing firms, overall, perceptions of the effectiveness of the police and courts among these respondents appear decidedly skeptical.

PROTECT2 is a measure of the official and unofficial security payments made by the firm. In this analysis, firms scoring 2.5 are defined as having an "average" level of perceived security. Firms scoring above 3.0 are defined as having a security situation that requires them to make "above average" payments in order to offset the risk associated with destruction or expropriation. Firms scoring below 2.0 are defined as having a relatively secure situation with regard to the protection of property and property rights. The mean score on PROTECT2 for the firms participating in this survey is 2.96. As seen in column 2, service sector firms tend to fare marginally better in terms of property protection. Once again, firms in Vladivostok stand out: in this instance, they pay a significantly lower price for 


\section{William Davidson Institute Working Paper 469}

security.

Column 3 of Table 2, EXTORT, summarizes the response patterns for the two questions regarding the payment of bribes. The mean score on the extortion index for participating firms is 1.29. Firms in Vladivostok scored significantly lower (0.48) than the mean. Firms in Rostov and Taganrog scored significantly higher. Interestingly enough, producers and/or distributors of consumer durables (including electronic equipment) scored the highest on the extortion index (1.38) and scored the lowest in terms of their view of the effectiveness of the police and courts, PROTECT1 (.21). The negative correlation holds, albeit somewhat weakly, for the entire group of participating firms; that is, the correlation coefficient between PROTECT1 and EXTORT is - .2585 .

The last column of Table 2 summarizes the firms' experience with regard to external financing. Generally, access to external financing is low among the firms participating in this survey; the mean score on CREDIT is 0.78 (out of 4.0). Firms in Moscow stand out as having the greatest access to credit (1.75), especially relative to comparable firms in the other regions (0.54).

The results presented in Table 2 suggest that Russian firms do not perceive their property or property rights as secure. Nor do they report much experience with external financing. Neither outcome, relative lack of security and relative lack of external financing, is dependent upon whether the firm owns or leases the company's premises. That is, firms with collateral (they report owning their premises) are no more likely to undertake external financing than firms which lease their premises.

What factors determine the percentage of profits that Russian firms reinvest? Table 3 presents the regression results, where reinvest is the dependent variable. In the first specification, the independent variables consist of the two components of the security index, PROTECT1 and 
PROTECT2, and the credit index, with a control variable for location in Moscow. As seen in the first column, the percentage of profits reinvested is significantly higher among firms with a positive perception of the effectiveness of the police and courts (PROTECT1), and significantly lower among firms making protection payments (PROTECT2). The relative impact of both the positive (8.0\%) and negative (7.7\%) components of the security index is approximately the same. Access to external financing has a positive impact on the percentage of profits reinvested by the firm, albeit smaller than the impact of property protection. In comparison to the relative importance of property protection or access to financing, location in Moscow has a much larger influence on the firm decision to reinvest profits.

The second specification uses the extortion index to capture the firm's perception of the security of property and property rights (column 2). Among firms making bribe payments (EXTORT), the percentage of profits reinvested is significantly lower. This specification has about the same explanatory power as the first, suggesting that the payment of bribes is a more important indicator than any combination of official protection payments. Moreover, the coefficient (EXTORT) is nearly three times larger than the coefficient on access to financing (CREDIT). Location in Moscow continues to have a positive impact on the firm's reinvestment allocation.

In the third specification, dummy variables are included to capture differences in investment strategies across sectors of the economy. Sectors are defined by type of product; for example, both food processing and food distribution firms are included in FOOD. DURABLES includes both the producers and distributors of consumer durables. Heavy industry, which includes both the producers and distributors of machinery and other heavy industry items, is the omitted sector in this analysis. PROTECT1 and PROTECT2 are used to capture the managers' perceptions of the security position of 


\section{William Davidson Institute Working Paper 469}

their firms. Once again, the percentage of profits reinvested is higher among firms with a positive perception of the effectiveness of the police and courts, and lower among firms making protection payments. Access to credit has a positive impact on reinvestment, as does location in Moscow. In comparison to heavy industry firms, firms in food processing and "other industry and services" reinvest a significantly higher fraction of their profits. The next specification provided in Table 3 (column 4) substitutes the extortion index, EXTORT, for PROTECT1 and PROTECT2, and despite the reduction in the number of variables included in the specification, the explanatory power rises. The basic pattern remains the same: (1) extortion (lack of security) reduces reinvestment by $18 \%$; (2) access to external financing raises reinvesment by 5\%; (3) firms in Moscow reinvest at least 20\% more than firms in the other regions.

Do manufacturing firms differ from retail shops and other service sector firms in terms of their reinvestment strategy? As seen in column 5, the manufacturing firms in this survey reinvested a significantly smaller fraction of their profits.

The final specification in this panel of Table 3 takes into account the financial position of the firm and the availability of collateral for loans. The best proxy for the firm's financial position was the reported level of average wages paid to employees. The proxy for the availability of collateral is whether or not the firm reports owning its premises. As seen in column 6, firms which pay above average wages (are in good financial condition) reinvest a significantly greater portion of their profits. Indeed, including this variable significantly increases the explanatory power of the equation. That the coefficient on location in Moscow loses significance is explained by the high degree of correlation between high wages and Moscow. The availability of collateral (LEASE) has no significant effect on the 


\section{William Davidson Institute Working Paper 469}

firm's reinvestment behavior.

In the second panel of Table 3, workforce size is included as an explanatory variable in the reinvestment decision (column 7), as are changes in the firm's sales volume (VOLUME) and financial position (POSITION) over the past year (see column 8). No new results emerge.

In column 9, the additive credit index is replaced by a dummy variable, LOAN, which equals one if the firm has received any external financing. This specification has approximately the same explanatory power as the first (column 1), but the coefficient on LOAN is nearly twice that on CREDIT, suggesting that access to financing is more important than the availability of multiple sources.

The specification reported in column 10 is to be compared with column 2, where EXTORT replaces PROTECT1 and PROTECT2 as the measure of security. In column 11, the sector variables are added to the specification, for comparison with column 3.

Overall, the results emerging from these data are remarkably robust. Firms which face a lack of security reinvest a significantly smaller fraction of their profits. The effect is strongest among firms making bribe payments. Firms with access to credit reinvest a significantly greater share of their profits. Firms located in Moscow reinvest significantly more than firms elsewhere. Only when average wage is included, which is highly correlated with Moscow, does the "capital city effect" become insignificant. Firms in the food processing and food distribution sector reinvest a significantly higher share of their profits, as do firms in "other industry and services." Manufacturing firms reinvest significantly less, in comparison to retail shops and other service sector firms.

\section{Conclusions}

Six hypotheses governed the development of both a security index and credit index in this 


\section{William Davidson Institute Working Paper 469}

investigation of the factors which influence the investment activities of Russian firms. Data collected from 264 Russian firms in the spring and fall of 2001 were used to evaluate the relative importance of property protection and access to credit on the decision by firms to reinvest their profits. Property protection emerges as nearly twice as important as access to external financing in terms of explaining the percentage of profit that the firm reinvested. ${ }^{31}$ These results send a clear signal that simply injecting money into the banking system - loosening credit constraints in the economy - will not reverse the decision of Russian firms to reinvest a relatively small portion of their profits back into the company. More important, from the perspective of the firms participating in this study, is for policymakers to devise a way to protect the property and property rights of Russian businesses. The cost of not doing so appears to be an investment level $10 \%$ lower than it could be given the existing financial situation.

While this percentage may seem low, in the absence of rule of law it has compounded each year for the past decade, imposing upon the Russian people a transition cost far higher than warranted.

\footnotetext{
31 The one exception occurs when security is measured by the existence of bribe payments and credit access is measured using a dummy variable which equals one if external financing is available. In this specification (Table 3 , column 12), both property protection and credit access have approximately the same effect on the percentage of profits reinvested.
} 
William Davidson Institute Working Paper 469

Table 1: Characteristics of Participating Firms

\begin{tabular}{|c|c|c|c|c|c|c|c|c|}
\hline \multirow[b]{2}{*}{ Number of Firms } & \multicolumn{2}{|c|}{$\begin{array}{r}\text { Moscow } \\
\text { Frequency } \%\end{array}$} & \multicolumn{2}{|c|}{$\begin{array}{c}\text { Rostov } \\
\text { Frequency \% }\end{array}$} & \multicolumn{2}{|c|}{$\begin{array}{l}\text { Taganrog+ } \\
\text { Frequency \% }\end{array}$} & \multicolumn{2}{|c|}{$\begin{array}{c}\text { Vladivostok } \\
\text { Frequency \% }\end{array}$} \\
\hline & 40 & 15 & 35 & 13 & 139 & 53 & 50 & 19 \\
\hline \multicolumn{9}{|l|}{ Year Established* } \\
\hline before 1992 & 1 & 2.5 & 0 & 0 & 1 & 1.2 & 3 & 8.5 \\
\hline 1992 & 4 & 10.0 & 1 & 7.1 & 8 & 9.7 & 1 & 2.8 \\
\hline 1993-1995 & 13 & 32.5 & 4 & 28.6 & 16 & 19.5 & 8 & 22.8 \\
\hline $1996-1998$ & 17 & 56.7 & 6 & 42.8 & 34 & 41.4 & 15 & 42.8 \\
\hline since 1998 & 5 & $\underline{12.5}$ & 3 & $\underline{21.4}$ & $\underline{23}$ & $\underline{28.0}$ & 8 & $\underline{22.8}$ \\
\hline Total & $\overline{40}$ & 100 & $\overline{14}$ & 100 & $\overline{82}$ & 100 & $\overline{35}$ & 100 \\
\hline \multicolumn{9}{|l|}{ Type of Firm } \\
\hline Manufacturing & 0 & 0 & 22 & 62.8 & 43 & 30.9 & 14 & 28.0 \\
\hline Retail & 40 & 100 & 10 & 28.6 & 52 & 37.4 & 20 & 40 \\
\hline Other & 0 & 0 & 3 & 8.6 & 44 & 31.7 & $\underline{16}$ & 32 \\
\hline Total & $\overline{40}$ & 100 & $\overline{35}$ & 100 & $\overline{139}$ & $\overline{100}$ & $\overline{50}$ & $\overline{100}$ \\
\hline Food & 33 & 82.5 & 4 & 11.4 & 42 & 30.2 & 17 & 34.0 \\
\hline Consumer goods & 5 & 12.5 & 10 & 28.6 & 13 & 9.3 & 3 & 6.0 \\
\hline Durables & 2 & 5.0 & 9 & 25.7 & 26 & 18.7 & 6 & 12.0 \\
\hline Heavy industry & 0 & 0.0 & 4 & 11.4 & 8 & 5.8 & 1 & 2.0 \\
\hline Construction materials & 0 & 0.0 & 3 & 8.6 & 17 & 12.2 & 3 & 6.0 \\
\hline Services/other & 0 & 0.0 & 5 & $\underline{14.3}$ & 33 & $\underline{23.7}$ & $\underline{20}$ & $\underline{40.0}$ \\
\hline Total & $\overline{40}$ & 100 & $\overline{35}$ & 100 & $\overline{139}$ & 100 & $\overline{50}$ & 100 \\
\hline \multicolumn{9}{|l|}{ Current workforce size } \\
\hline Firms with $<10$ workers & 7 & 17.5 & 0 & 0 & 15 & 10.8 & 16 & 32.0 \\
\hline 10-25 workers & 21 & 52.5 & 0 & 0 & 46 & 33.1 & 24 & 48.0 \\
\hline $26-100$ workers & 9 & 22.5 & 9 & 25.7 & 32 & 23.0 & 7 & 14.0 \\
\hline $101-200$ workers & 3 & 7.5 & 14 & 40.0 & 14 & 10.1 & 0 & 0.0 \\
\hline$>200$ workers & $\underline{0}$ & 0 & 12 & 34.3 & 32 & 23.0 & 3 & 6.0 \\
\hline Total & $\overline{40}$ & $\overline{100}$ & 35 & 100 & 139 & 100 & $\overline{50}$ & $\overline{100}$ \\
\hline & \multicolumn{2}{|c|}{ Moscow } & \multicolumn{2}{|c|}{ Rostov } & \multicolumn{2}{|c|}{ Taganrog+ } & \multicolumn{2}{|c|}{ Vladivostok } \\
\hline Sample Charatcteristics & Mean & $N$ & Mean & $N$ & Mean & $\widetilde{N}$ & Mean & $N$ \\
\hline Average number of locations per firm* & 2.3 & 39 & 2.7 & 10 & 5.2 & 50 & 4.4 & 14 \\
\hline Average number of employees & 28 & 40 & 409 & 35 & 168 & 138 & 16 & 47 \\
\hline Average monthly wage (rubles) & 5214 & 40 & 2057 & 35 & 1458 & 139 & 4053 & 36 \\
\hline Average tax ( $\%$ of sales revenues) & 41.8 & 40 & 37.2 & 34 & 37.4 & 137 & 38.2 & 33 \\
\hline Percentage firms which own building(s) & 5.0 & 40 & 48.6 & 35 & 69.8 & 136 & 28.0 & 50 \\
\hline Percentage firms reporting profits & 92.5 & 40 & 88.6 & 35 & 77.5 & 138 & 74.0 & 50 \\
\hline Average percent profits reinvested & 61.6 & 37 & 11.4 & 31 & 16.1 & 107 & 69.1 & 35 \\
\hline Percentage of firms borrowing to & & & & & & & & \\
\hline cover working capital expenses & 77.5 & 40 & 8.6 & 35 & 21.0 & 138 & 22.0 & 50 \\
\hline $\begin{array}{l}\text { Percentage of firms borrowing } \\
\text { to cover wage bill }\end{array}$ & 10.5 & 38 & 0 & 34 & 9.1 & 121 & 11.1 & 45 \\
\hline
\end{tabular}


William Davidson Institute Working Paper 469

Table 1: Characteristics of Participating Firms (cont .)

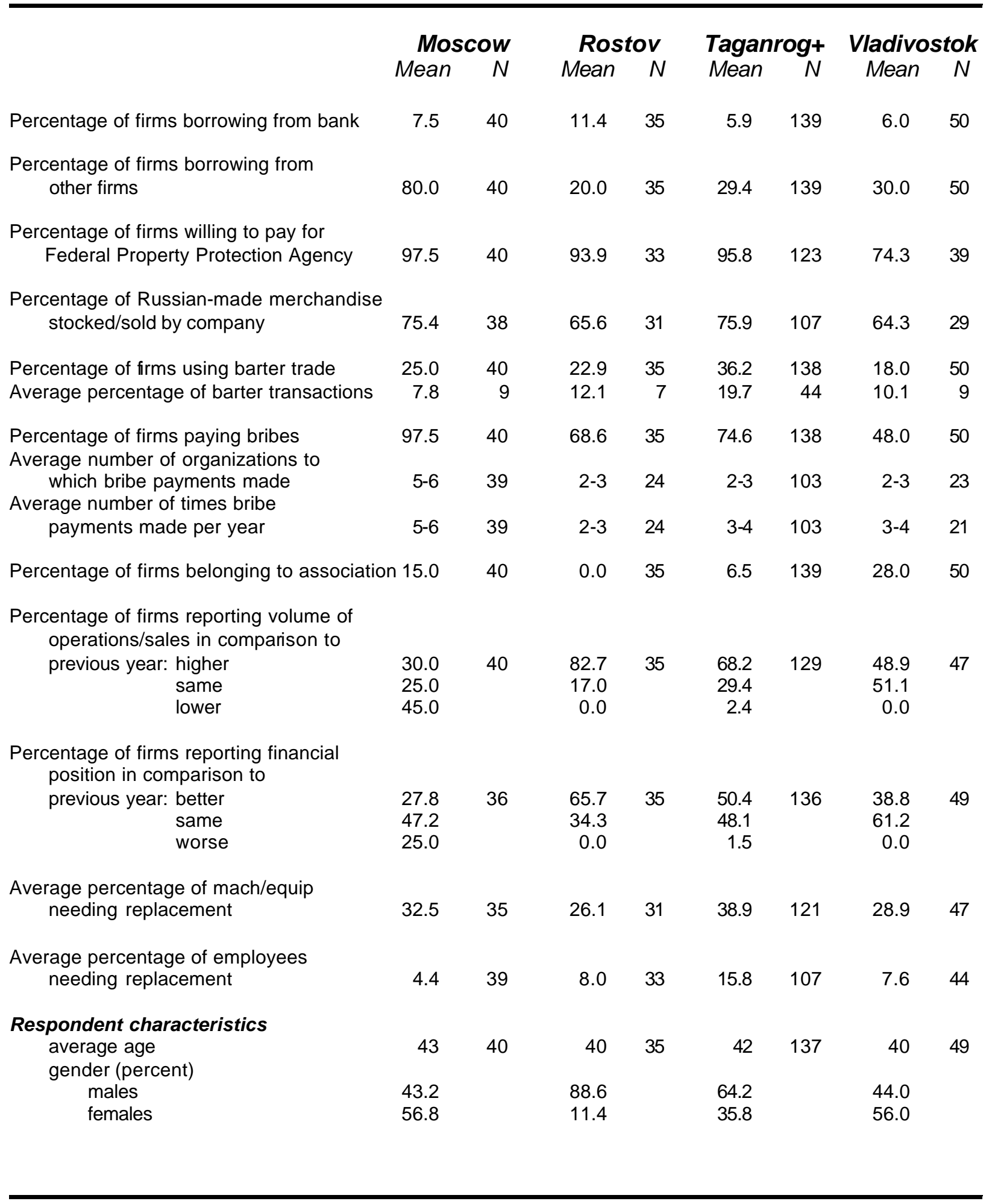

+ Includes Azov.

${ }^{*}$ Asked of retail shops and de novo firms only. 
Table 2: Property Protection and Credit Access

\begin{tabular}{|c|c|c|c|c|}
\hline & PROTECT1 & PROTECT2 & EXTORT & CREDIT \\
\hline \multicolumn{5}{|l|}{ Type of firm } \\
\hline Retail $(n=122)$ & .47 & 3.01 & 1.23 & .93 \\
\hline Manufacturing $(n=79)$ & .37 & 3.02 & 1.34 & .65 \\
\hline Service $(n=63)$ & .29 & 2.81 & 1.33 & .67 \\
\hline \multicolumn{5}{|l|}{ Main product/activity } \\
\hline Food $(n=95)$ & .54 & 3.14 & 1.33 & 1.02 \\
\hline Consumer goods $(n=31)$ & .35 & 2.98 & 1.16 & .71 \\
\hline Durables $(n=42)$ & .21 & 3.00 & 1.38 & .50 \\
\hline Heavy industry $(n=13)$ & .38 & 2.85 & 1.15 & 1.00 \\
\hline Construction materials $(n=23)$ & .43 & 3.04 & 1.30 & .70 \\
\hline Services/other $(n=57)$ & .32 & 2.63 & 1.21 & .58 \\
\hline \multicolumn{5}{|l|}{ Location } \\
\hline Moscow $(n=40)$ & .30 & 2.68 & 1.17 & 1.75 \\
\hline Rostov $(n=35)$ & .26 & 3.51 & 1.60 & .40 \\
\hline Taganrog $(n=139)$ & .36 & 3.29 & 1.52 & .65 \\
\hline Vladivostok $(\mathrm{n}=50)$ & .68 & 1.88 & .48 & .68 \\
\hline \multicolumn{5}{|l|}{ Ownership of buildings } \\
\hline Lease $(n=133)$ & .38 & 2.73 & 1.13 & .89 \\
\hline Own $(n=161)$ & .36 & 2.98 & 1.28 & .63 \\
\hline
\end{tabular}

Protect1: Maximum value $=3$.

Protect2: Maximum value $=5$.

Extort: Maximum value $=2$.

Credit: Maximum value $=4$ 
Table 3: Regression Results

\begin{tabular}{|c|c|c|c|c|c|c|c|c|c|c|c|c|}
\hline \multirow{2}{*}{$\begin{array}{l}\text { Variable } \\
\text { PROTECT1 }\end{array}$} & $\begin{array}{l}(1 \\
\text { coefficient }\end{array}$ & (1) & \multicolumn{2}{|c|}{ (2) } & $\begin{array}{r}\text { (3 } \\
\text { coefficient }\end{array}$ & t-stat & (4) & t-stat & $\begin{array}{r}(5) \\
\text { coefficient }\end{array}$ & t-stat & \multicolumn{2}{|c|}{$(6)$} \\
\hline & $\begin{array}{r}.080 \\
-.077\end{array}$ & $\begin{array}{c}2.60^{\star} \\
-5.43^{\star}\end{array}$ & & & $\begin{array}{r}.064 \\
-.084\end{array}$ & $\begin{array}{l}2.08^{\star \star} \\
-5.88^{\star}\end{array}$ & & & & & & \\
\hline EXTORT & & & -.174 & $-7.20^{\star}$ & & & -.183 & $-7.80^{*}$ & -.189 & $-8.21^{*}$ & -.111 & $-4.60^{*}$ \\
\hline CREDIT & .046 & $2.21^{\star \star}$ & .060 & $3.06^{\star}$ & .038 & $1.92^{\star \star}$ & .051 & $2.68^{*}$ & .051 & $2.75^{\star}$ & .043 & $2.52^{*}$ \\
\hline MOScOW & .268 & $5.07^{*}$ & .243 & $4.82^{*}$ & 239 & $4.17^{*}$ & .221 & $4.16^{*}$ & .175 & $3.27^{*}$ & -.020 & -.34 \\
\hline FOOD & & & & & .187 & $2.47^{*}$ & .196 & $2.71^{*}$ & .171 & $2.41^{\star *}$ & .169 & $2.63^{*}$ \\
\hline CGOODS & & & & & -.009 & -.10 & -.012 & -.14 & -.058 & -.69 & -.021 & -.29 \\
\hline DURABLES & & & & & .072 & .91 & .087 & 1.13 & .078 & 1.04 & .067 & .98 \\
\hline CONSTMAT & & & & & .110 & 1.29 & .111 & 1.35 & .103 & 1.29 & .106 & 1.46 \\
\hline SERVOTH & & & & & .208 & $2.69^{*}$ & .221 & $2.98^{*}$ & .174 & $2.35^{\star *}$ & .131 & $1.95^{\star *}$ \\
\hline MFG & & & & & & & & & -.121 & $-3.32^{*}$ & -.123 & $-3.60^{*}$ \\
\hline LNAVGWG & & & & & & & & & & & .229 & $5.97^{\star}$ \\
\hline LEASE & & & & & & & & & & & -.005 & -.15 \\
\hline Constant & .446 & $8.88^{*}$ & .467 & $12.26^{*}$ & .344 & $4.14^{\star}$ & .343 & $4.68^{\star}$ & .421 & $5.59^{\star}$ & -1.401 & $-4.62^{*}$ \\
\hline Adj R-squared & .3415 & & .3771 & & .3877 & & .4313 & & .4583 & & .5409 & \\
\hline Observations & $\mathrm{n}=21$ & & $\mathrm{n}=2$ & & $\mathrm{n}=2$ & & $\mathrm{n}=2$ & & $n=2$ & & $n=2$ & 201 \\
\hline
\end{tabular}

*Significant @ 1\%

**Significant @ 5\% 
William Davidson Institute Working Paper 469

Table 3: Regression Results (cont'd)

\begin{tabular}{|c|c|c|c|c|c|c|c|c|c|c|c|c|}
\hline \multicolumn{3}{|c|}{ Dependent variable $=\underset{(7)}{\text { REINVEST }}$} & \multicolumn{2}{|c|}{$\begin{array}{c}(8) \\
\text { coefficient } t \text {-stat }\end{array}$} & \multicolumn{2}{|c|}{$\begin{array}{c}(9) \\
\text { coefficient } t \text {-stat }\end{array}$} & \multicolumn{2}{|c|}{$\begin{array}{c}(10) \\
\text { coefficient } t \text {-stat }\end{array}$} & \multicolumn{2}{|c|}{$\begin{array}{c}(11) \\
\text { coefficient } t \text {-stat }\end{array}$} & \multicolumn{2}{|c|}{$\begin{array}{c}(12) \\
\text { coefficient } t \text {-stat }\end{array}$} \\
\hline $\begin{array}{l}\text { PROTECT1 } \\
\text { PROTECT2 }\end{array}$ & $\begin{array}{r}.077 \\
-.066\end{array}$ & $\begin{array}{l}2.58^{\star} \\
-4.41^{\star}\end{array}$ & $\begin{array}{r}.083 \\
-.060\end{array}$ & $\begin{aligned} & 2.73^{*} \\
- & 4.02^{*}\end{aligned}$ & $\begin{array}{r}.081 \\
-.976\end{array}$ & $\begin{array}{l}2.65^{\star} \\
-5.30^{*}\end{array}$ & & & & & & \\
\hline EXTORT & & & & & & & -.171 & $-7.05^{\star}$ & -.185 & $-8.07^{*}$ & -.107 & $-4.52^{*}$ \\
\hline $\begin{array}{l}\text { CREDIT } \\
\text { LOAN }\end{array}$ & .039 & $1.94^{\star *}$ & .045 & $2.16^{\star *}$ & .080 & $2.05^{\star *}$ & .106 & $2.83^{*}$ & .101 & $2.79^{*}$ & .090 & $2.82^{*}$ \\
\hline MOscow & .213 & $3.73^{*}$ & .251 & $4.12^{*}$ & .287 & $5.80^{*}$ & .269 & $5.64^{*}$ & .193 & $3.79^{*}$ & & \\
\hline $\begin{array}{l}\text { FOOD } \\
\text { CGOODS } \\
\text { DURABLES } \\
\text { CONSTMAT } \\
\text { SERVOTH }\end{array}$ & & & & & & & & & $\begin{array}{r}.175 \\
-.051 \\
.083 \\
.109 \\
.185\end{array}$ & $\begin{array}{l}2.47^{*} \\
-.61 \\
1.10 \\
1.35 \\
2.50^{*}\end{array}$ & $\begin{array}{r}.171 \\
.015 \\
.070 \\
.110 \\
.143\end{array}$ & $\begin{array}{l}2.73^{\star} \\
-.20 \\
1.04 \\
1.53 \\
2.15^{\star \star}\end{array}$ \\
\hline MFG & -.073 & -1.61 & & & & & & & -.123 & $-3.36^{*}$ & -.121 & $-3.78^{*}$ \\
\hline LNAVGWG & & & & & & & & & & & .223 & $7.64^{*}$ \\
\hline LEASE & -.035 & -.92 & & & & & & & & & & \\
\hline $\begin{array}{l}\text { VOLUME } \\
\text { POSITION }\end{array}$ & & & $\begin{array}{l}-.006 \\
-.013\end{array}$ & $\begin{array}{l}-.16 \\
-.33\end{array}$ & & & & & & & & \\
\hline $\begin{array}{l}\text { WKSIZE1 } \\
\text { WKSIZE2 } \\
\text { WKSIZE4 } \\
\text { WKSIZE5 }\end{array}$ & $\begin{array}{l}.169 \\
.045 \\
.024 \\
-.327\end{array}$ & $\begin{array}{c}2.78^{\star} \\
1.02 \\
.38 \\
-.57\end{array}$ & $\begin{array}{l}.143 \\
.042 \\
-.004 \\
-.083\end{array}$ & $\begin{array}{c}2.28^{\star} \\
.94 \\
-.56 \\
-1.54\end{array}$ & & & & & & & & \\
\hline Constant & .469 & $5.85^{*}$ & .411 & $5.12^{*}$ & .439 & $8.60^{*}$ & .460 & $11.80^{*}$ & .406 & $5.33^{*}$ & -1.38 & $-5.73^{*}$ \\
\hline Adj R-squared & .3908 & & .3622 & & .3392 & & .3625 & & .4587 & & .5488 & \\
\hline Observations & & 207 & & 195 & & 210 & & 210 & & 210 & & 201 \\
\hline
\end{tabular}

* Significant @ 1\%

** Significant @ 5\% 
William Davidson Institute Working Paper 469

\section{Appendix A}

Variable List: Definition, Mean value

\begin{tabular}{|c|c|c|c|c|c|c|}
\hline Variable name & & Definition & & Mean & & $\mathrm{Ob}$ \\
\hline REINVEST & & $\%$ profit reinvested in the firm & & .322 & & \\
\hline MILITSIA & & police work well/effectively to protect property & & .054 & & 264 \\
\hline SATISFY & & satisfied with efforts of police when called & & .220 & & \\
\hline COURTWEL & & courts work well/effectively to protect property & & .132 & & \\
\hline PROTECT1 & & index of police and court effectiveness ( $\max$ value $=$ & $=3)$ & .398 & & \\
\hline ASKPOLC & & did firm ask police for assistance & .254 & & 264 & \\
\hline SECURITY & & does firm employ security personnel & & .716 & & \\
\hline BUYSEC & & does firm employ other organization to provide secu & arity & .708 & & 04 \\
\hline BRIBE & & did company make bribe payments last year & & .720 & & 64 \\
\hline BRIBECRT & & would bribe payment avoid court appearance & & .568 & & 64 \\
\hline PROTECT2 & & index of protection payments $(\max$ value $=5)$ & & 2.966 & & \\
\hline EXTORT & & index of bribe payments ( $\max$ value $=2$ ) & 1.288 & & 264 & \\
\hline RENOVATE & & plans for major repairs & & .207 & & 01 \\
\hline VOLUME & & volume of sales/operations this year compared to las & & 1.481 & & 51 \\
\hline POSITION & & financial position this year compared to last & & 1.587 & & . \\
\hline BORROW & & borrow for working capital & & .280 & & 64 \\
\hline BOROWW & & borrow to pay wages & & .076 & & 264 \\
\hline BANKLOAN & & borrow from bank & & .068 & & 264 \\
\hline LOANPVT & & borrow from private individual or company & & .356 & & 64 \\
\hline CREDIT & & index of access to external financing ( $\max$ value $=4$ & & .780 & & 264 \\
\hline LOAN & & dummy variable $=1$ if any external financing & & .409 & & 64 \\
\hline MOSCOW & & dummy variable $=1$ if firm located in Moscow & & .152 & & \\
\hline ROSTOV & & dummy variable $=1$ if firm located in Rostov & & .132 & & 64 \\
\hline TAGANROG & & dummy variable $=1$ if firm located in Taganrog, Azc & & .525 & & 264 \\
\hline VLADSTOK & & dummy variable $=1$ if firm located in Vladivostok & .189 & & 264 & \\
\hline RETAIL & & dummy variable $=1$ if firm is retail shop & .462 & & 264 & \\
\hline MFG & & dummy variable $=1$ if firm is manufacturing & & .299 & & \\
\hline SERVICE & & dummy variable $=1$ if firm is non-retail, non-mfg & .238 & & 264 & \\
\hline FOOD & & dummy variable $=1$ if food production/distribution & & .360 & &  \\
\hline CGOODS & & dummy variable $=1$ if consumer goods production $/ \mathrm{c}$ & dist & .117 & & 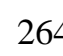 \\
\hline DURABLES & & dummy variable $=1$ if consumer durables & .159 & & 264 & \\
\hline HEAVY & dummy & variable $=1$ if heavy industry $/$ mch bldg $\quad .049$ & & 264 & & \\
\hline CONSTMAT & & dummy variable $=1$ if construction materials & & .087 & & 20 \\
\hline SERVOTH & & dummy variable $=1$ if service, other & & .216 & & 64 \\
\hline LEASE & dummy & variable $=1$ if firm leases premises & .504 & & 264 & \\
\hline
\end{tabular}




\section{William Davidson Institute Working Paper 469}

Variable name

AVGWAGE

LNAVGWG

WKSIZE1

WKSIZE2

WKSIZE3

WKSIZE4

WKSIZE5

VOLUME

POSITION

\section{Definition}

average wage

ln average wage

dummy variable $=1$ if workforce size $<10$

dummy variable $=1$ if workforce size 10-25

dummy variable $=1$ if workforce size 26-50

dummy variable $=1$ if workforce size $51-200$

dummy variable $=1$ if workforce size $>200$

sales volume this year in comparison to last year

$1=$ higher, 2 = same, 3 = lower

financial position this year in comparison to last year $1=$ better, 2 = same, $3=$ worse,
Mean

2516.6

250

$.144 \quad 264$

$.345 \quad 264$

$.216 \quad 264$

$.117 \quad 264$

$.178 \quad 264$

251

1.578

256 
William Davidson Institute Working Paper 469

References

Braguinsky, Serguey and Grigory Yavlinsky. 2000. Incentives and Institutions: The Transition to a Market Economy in Russia (Princeton NJ: Princeton University Press).

Demirguc-Kunt, Asli and Vojislav Maksimovic. 1998. "Law, Finance, and Firm Growth,” Journal of Finance, vol 53, no 6 (December), pp. 2107-2137.

Friedman, Eric, Simon Johnson, Daniel Kaufmann and Pablo Zoido-Lobaton. 2000. "Dodging the Grabbing Hand: Determinants of Unofficial Activity in 69 Countries," Journal of Public Economics vol 76, pp. 459-494.

Frye, Timothy and Andrei Shleifer. 1997. "The Invisible Hand and the Grabbing Hand," American Economic Review Papers and Proceedings vol 87 (May), pp. 554-559.

Frye, Timothy and Ekaterian Zhuravskaya. 1999. "Rackets, Regulation and the Rule of Law," unpublished manuscript, Ohio State University.

Gaviria, Alejandro. 2000. "Assessing the Effects of Corruption and Crime on Firm Performance," InterAmerican Development Bank, Washington D.C. (December).

Grossman, S and E. Helpman. 1994. "Protection for Sale," American Economic Review vol 84, pp. 833-850.

Hellman, Joel and Mark Schankerman. 2000. "Intervention, Corruption, and Capture: The Nexus between Enterprises and the State," Economics of Transition, vol 8, no 3 , pp 545-576.

Johnson, Simon, John McMillan and Christopher Woodruff. 1999a. "Contract Enforcement in Transition," unpublished manuscript, Sloan School of Management, MIT (January).

Johnson, Simon, John McMillan and Christopher Woodruff. 1999b. "Property Rights, Finance and Entrepreneurship," unpublished manuscript, Sloan School of Management, MIT (June).

Johnson, Simon, Daniel Kaufmann, John McMillan and Christopher Woodruff. 2000. "Why Do Firms Hide? Bribes and Unofficial Activity after Communism,” Journal of Public Economics vol 76, pp. 495520.

Knack, Stephen and Philip Keefer. 1995. "Institutions and Economic Performance: Cross-Country Tests Using Alternative Institutional Measures," Economics and Politics vol 7 no 3 (November), pp. 207228.

Linz, Susan J. 2000. "Labor Productivity in Russian Industry: A Regional Analysis," Economic Development and Cultural Change vol 48, no 4 (July), pp. 685-718.

Linz, Susan J. and Gary Krueger. 1998. "Enterprise Restructuring in Russia’s Transition Economy: Formal and Informal Mechanisms," Comparative Economic Studies vol 40, no 2 (Summer), pp. 5-52. 


\section{William Davidson Institute Working Paper 469}

Mauro, Paolo. 1995. “Corruption and Growth," Quarterly Journal of Economics, vol 110, no 3 (August), pp. 681-712.

Pissarides, Francesca, Miroslav Singer and Jan Svejnar. 2000. "Objectives and Constraints of Entrepreneurs: Evidence from Small and Medium-Sized Enterprises in Russia and Bulgaria," ERBD Working Paper No 59 (November).

Rajan, Raghuram and Luigi Zingales. 1998. "Financial Dependence and Growth," American Economic Review vol 88, no 3 (June), pp. 559-586.

Svensson, Jakob. 1998. "Investment, Property Rights and Political Instability: Theory and Evidence," European Economic Review vol 42, pp. 1317-1341. 


\section{DAVIDSON INSTITUTE WORKING PAPER SERIES - Most Recent Papers}

The entire Working Paper Series may be downloaded free of charge at: www.wdi.bus.umich.edu

CURRENT AS 5/22/02

\begin{tabular}{|c|c|c|}
\hline Publication & Authors & Date \\
\hline $\begin{array}{l}\text { No. 469: Barriers to Investment by Russian Firms: Property Protection } \\
\text { or Credit Constraints? }\end{array}$ & Susan J. Linz & May 2002 \\
\hline No. 468: Job Satisfaction Among Russian Workers & Susan J. Linz & May 2002 \\
\hline $\begin{array}{l}\text { No. 467: Assessing the Problem of Human Capital Mismatch in } \\
\text { Transition Economies }\end{array}$ & $\begin{array}{l}\text { Viliam Druska, Byeong ju Jeong, } \\
\text { Michal Keja k, and Viatcheslav } \\
\text { Vinogradov }\end{array}$ & Mar. 2002 \\
\hline $\begin{array}{l}\text { No. 466: Motivating Russian Workers: Analysis of Age and Gender } \\
\text { Differences }\end{array}$ & Susan J. Linz & Feb. 2002 \\
\hline No. 465: Virtual Reality: Barter and Restructuring in Russian Industry & Gary Krueger and Susan J. Linz & Apr. 2001 \\
\hline $\begin{array}{l}\text { No. 464: Lending of Last Resort, Moral Hazard and Twin Crises: } \\
\text { Lessons from the Bulgarian Financial Crisis 1996/1997 }\end{array}$ & $\begin{array}{l}\text { Michael Berlemann, Kalin } \\
\text { Hristov and Nikolay Nenovsky }\end{array}$ & May 2002 \\
\hline $\begin{array}{l}\text { No. 463: Deindustrialisation. Lessons from the Structural Outcomes of } \\
\text { Post-Communist Transition }\end{array}$ & $\begin{array}{l}\text { Tomasz Mickiewicz and Anna } \\
\text { Zalewska }\end{array}$ & Jan. 2002 \\
\hline $\begin{array}{l}\text { No. 462: Joint Liability Lending and the Rise and Fall of China's } \\
\text { Township and Village Enterprises }\end{array}$ & Albert Park and Minggao Shen & July 2001 \\
\hline $\begin{array}{l}\text { No. 461: A Refinancing Model of Decentralization with Empirical } \\
\text { Evidence from China }\end{array}$ & Albert Park and $\mathrm{M}$ & Apr. 2002 \\
\hline $\begin{array}{l}\text { No. 460: The Effects of Market Liberalization on the Relative Earnings } \\
\text { of Chinese Women }\end{array}$ & $\begin{array}{l}\text { Margaret Maurer-Fazio and } \\
\text { James Hughes }\end{array}$ & Mar. 2002 \\
\hline $\begin{array}{l}\text { No. 459: The Role of Education in Determining Labor Market } \\
\text { Outcomes in Urban China's Transitional Labor Markets }\end{array}$ & Margaret Maurer-Fazio & Apr. 2002 \\
\hline $\begin{array}{l}\text { No. 458: Real and Monetary Convergence within the European Union } \\
\text { and Between the European Union and Candidate Countries: } \\
\text { A Rolling Cointegration Approach }\end{array}$ & $\begin{array}{l}\text { Josef C. Brada, Ali M. Kutan and } \\
\text { Su Zhou }\end{array}$ & Apr. 2002 \\
\hline No. 457: Credit Ratings as Coordination Mechanisms & $\begin{array}{l}\text { Arnoud W. A. Boot and Todd T. } \\
\text { Milbourn }\end{array}$ & Mar. 2002 \\
\hline $\begin{array}{l}\text { No. 456: Balkan and Mediterranean Candidates for European Union } \\
\text { Membership: The Convergence of their Monetary Policy with that of the } \\
\text { European Central Bank }\end{array}$ & Josef C. Brada and Ali M. Kutan & Apr. 2002 \\
\hline $\begin{array}{l}\text { No. 455: Russian Financial Transition: The Development of Institutions } \\
\text { and Markets for Growth }\end{array}$ & David M. Kemme & Oct. 2001 \\
\hline $\begin{array}{l}\text { No. 454: Does the Market Pay Off? Earnings Inequality and Returns to } \\
\text { Education in Urban China }\end{array}$ & Xiaogang $\mathrm{Wu}$ and $\mathrm{Yu} \mathrm{Xie}$ & Apr. 2002 \\
\hline $\begin{array}{l}\text { No. 453: Entrepreneurs' Access to Private Equity in China: } \\
\text { The Role of Social Capital }\end{array}$ & Bat Batjargal and Mannie M. Liu & Apr. 2002 \\
\hline $\begin{array}{l}\text { No. 452: The Determinants of Privatised Enterprise Performance in } \\
\text { Russia }\end{array}$ & $\begin{array}{l}\text { Alan A. Bevan, Saul Estrin, Boris } \\
\text { Kuznetsov, Mark E. Schaffer, } \\
\text { Manuela Angelucci, Julian } \\
\text { Fennema and Giovanni } \\
\text { Mangiarotti }\end{array}$ & June 2001 \\
\hline $\begin{array}{l}\text { No. 451: Determinants of Financial Distress: What Drives Bankruptcy } \\
\text { in a Transition Economy? The Czech Republic Case }\end{array}$ & Lubomír Lízal & Jan. 2002 \\
\hline No. 450: Corporate Governance and the Global Social Void & Lee A. Tavis & Oct. 2001 \\
\hline $\begin{array}{l}\text { No. 449: Financial Architecture and Economic Performance: } \\
\text { International Evidence }\end{array}$ & Solomon Tadesse & Aug. 2001 \\
\hline $\begin{array}{l}\text { No. 448: Growth Slowdown Under Central Planning: A Model of Poor } \\
\text { Incentives }\end{array}$ & Zuzana Brixiová and Aleš Bulír & Mar. 2002 \\
\hline $\begin{array}{l}\text { No. 447: Disentangling Treatment Effects of Polish Active Labor } \\
\text { Market Policies: Evidence from Matched Samples }\end{array}$ & $\begin{array}{l}\text { Jochen Kluve, Hartmut Lehmann, } \\
\text { and Christoph M. Schmidt }\end{array}$ & Jan. 2002 \\
\hline $\begin{array}{l}\text { No. 446: The Impact of Socialist Imprinting and Search for Knowledge } \\
\text { on Resource Change: An Empirical Study of Firms in Lithuania }\end{array}$ & $\begin{array}{l}\text { Aldas Kriauciunas and Prashant } \\
\text { Kale }\end{array}$ & Mar. 2002 \\
\hline
\end{tabular}

